Forestry and Grassland Received on: 15/09/2019

Accepted on: 06/10/2020

\title{
Phosphorus fertilization in the implantation of a silvopastoral system: morphogenic and structural characteristics of Mombaça grass
}

\author{
Adubação fosfatada na implantação de sistema silvipastoril: características \\ morfogênicas e estruturais do capim Mombaça
}

PACHECO, Thais Valéria Souza Silva ${ }^{1 *}$ https://orcid.org/0000-0002-1861-8365

SOUSA, Luciano Fernandes ${ }^{2}$

https://orcid.org/0000-0002-6072-9237

SANTOS, Antônio Clementino dos ${ }^{2}$ https://orcid.org/0000-0001-7943-7923
SANTOS, José Geraldo Donizetti dos ${ }^{2}$ https://orcid.org/0000-0001-5818-9158

DIM, Valdinéia Patrícia ${ }^{3}$

https://orcid.org/0000-0001-8469-8095

SILVA, Hiran Marcelo Siqueira da ${ }^{4}$ https://orcid.org/0000-0002-6095-7643

PACHECO, Weverton Filgueira ${ }^{5}$

https://orcid.org/0000-0003-2101-6258

${ }^{1}$ Discente do Curso de Doutorado, Programa de Pós-Graduação em Ciência Animal Tropical, Universidade Federal do Tocantins, UFT, Araguaína, TO, Brasil.

${ }^{2}$ Docentes do Programa de Pós-Graduação em Ciência Animal Tropical, Universidade Federal do Tocantins, UFT, Araguaína, TO, Brasil.

${ }^{3}$ Docente da Faculdade de Ensino Superior da Amazônia Reunida, Redenção, PA, Brasil.

${ }^{4}$ University of, Florida, Ona, FL, USA.

${ }^{5}$ Docente do Instituto Federal de Educação, Ciência e Tecnologia do Maranhão, Grajaú, MA, Brasil.

*Corresponding author: tvaleria_18@hotmail.com

\section{RESUMO}

Objetivou-se avaliar o efeito da adubação fosfatada nas características morfogênicas e estruturais do capim Mombaça sob condições de implantação de sistema silvipastoril com eucaliptos e monocultivo no ecótono Amazônia/Cerrado. $\mathrm{O}$ experimento foi conduzido na UFT-EMVZ, nas estações chuvosas dos anos agrícolas de 2016/2017 e 2017/2018. Área experimental foi subdividida em dois sistemas de cultivo, Monocultivo de capim Mombaça, com 0,25 hectare e Silvipastoril com consórcio de eucalipto e capim Mombaça com área de 0,75 hectare. O delineamento utilizado foi um Delineamento inteiramente casualizado em esquema fatorial 4 a 2 sendo quatro doses de fósforo $(0 ; 50 ; 100 ; 200 \mathrm{~kg}$. $\mathrm{ha}^{-1}$ de $\mathrm{P}_{2} \mathrm{O}_{5}$. ano- ${ }^{-1}$ ) e dois sistemas de cultivo (monocultivo e silvipastoril), com três repetições. Foram avaliados três ciclos por período de descanso médio de 21 dias. Semanalmente foram realizadas as medições para avaliação das características estruturais e morfogênicas das plantas. De forma geral, fatores testados como adubação fosfatada, sistema de cultivo e ano de condução (implantação e ano seguinte) apresentaram 
influência, alterando o desenvolvimento do capim Mombaça, refletindo nas características morfogênicas e estruturais. As variáveis: densidade populacional de perfilhos, taxa de crescimento cultural, índice de área foliar, obtiveram interações entre a adubação fosfatada e os sistemas de cultivos analisados $(\mathrm{P}<0,05)$. A adubação fosfatada utilizada na implantação momento este de a de maior requerimento da planta, refletiu no desenvolvimento da forrageira aumentando a taxa de crescimento cultural, aparecimento foliar, bem como alongamento de folhas e colmo nos dois sistemas avaliados.

Palavras-chave: Eucalyptus urograndis, Fósforo, Integração pecuária-floresta, Megathyrsus maximum.

\begin{abstract}
The objective of this study was to evaluate the effect of phosphate fertilization on morphogenic and structural characteristics of Mombasa grass under conditions of implantation of silvopastoral system with eucalyptus and monoculture in the Amazon/Cerrado ecotone. The experiment was conducted at UFT-EMVZ during the rainy seasons of the 2016/2017 and 2017/2018 agricultural years. The experimental area was subdivided into two cultivation systems, Mombaça grass monoculture, with 0.25 hectare and silvopastoral system, intercropping eucalyptus with Mombaça grass, with 0.75 hectare area. The design used was a $4 \times 2$ factorial IHD with four doses of phosphorus $\left(0 ; 50 ; 100 ; 200\right.$ kg.ha ${ }^{-1} \mathrm{P}_{2} \mathrm{O}_{5}$ year- $\left.^{-1}\right)$ and two cultivation systems (monoculture and silvopastoral) with three repetitions. Three cycles were evaluated for an average rest period of 21 days. Weekly measurements were taken to evaluate structural and morphogenic characteristics of plants. In general, factors tested such as phosphorus fertilization, cultivation system and year (implantation and following year) showed influence, altering the development of Mombaça grass, reflecting on the morphogenic and structural characteristics. Tiller population density, crop growth rate, leaf area index showed interactions between phosphorus fertilization and the cultivation systems analyzed $(\mathrm{P}<0.05)$. Phosphorus fertilization used in the implantation, moment of greatest requirement of the plant, influenced forage development by increasing the crop growth rate, leaf appearance, as well as leaf and stem elongation in the two evaluated systems.
\end{abstract}

Keywords: Eucalyptus urograndis, Livestock-forest integration, Phosphorus, Megathyrsus maximum,

\section{INTRODUCTION}

Phosphorus is found in extremely low concentrations in the vast majority of Brazilian soils including the soils of the Amazon /Cerrado ecotone, especially considering the Quartzarênico Neosol. Phosphorus has low mobility and high adsorption capacity with clays typical of low slope areas such as kaolinites. Phosphorus is considered the very limiting nutrient for biomass production in Brazilian tropical soils (SANTOS et al., 2011).

The application of phosphate fertilizers has been used to meet the deficiencies in $\mathrm{P}$, so that the demand for phosphate fertilizers in Brazil has increased 
significantly in recent years, from 1,522 thousand tons in 2011, to 5,126 thousand tons in 2017 (ANDA, 2017).

The supply of phosphorus for crops such as pastures will depend on their concentrations in the soil solution, in addition to the soil ability to maintain adequate nutrient levels for the plant. Since the increased need for $P$ in Quartzarênico Neosol is related to low concentrations of organic matter and clay, making it impossible to retain large amounts of $\mathrm{P}$ applied (SILVA et al., 2016).

The recovery of pastures through silvopastoral systems (Ssp's) appears as a possible alternative for the expansion of Brazilian livestock, especially in the Amazon/Cerrado ecotone region (DIAS FILHO, 2011). Currently, Ssp's are one of the tools to solve the problem of depletion of natural resources, as these systems have a tree-pasture-animal combination in the same ecosystem. This can result in greater cycling in contrast to the loss of resources (EMBRAPA, 2015). The increase in OM concentration in soils is one of the advantages attributed to Ssp's and as soluble phosphate fertilizers have their efficiency increased in soils with a higher concentration of $\mathrm{OM}$.

In the Amazon/Cerrado ecotone, studies of tissue flow in pastures by means of morphogenic processes have become an important tool for the evaluation, use and increase in the production of leaves and tillers. In the last decades, management of tropical forage plants has undergone constant changes. In an energetic system, which seeks the interaction between the components of these pastures (Soil, Plant and Animal), the forage plant started to be studied as part of this system (CARVALHO et al., 2014).

Thus, the goal was to evaluate the effect of phosphorus fertilization on the morphogenic and structural characteristics of Mombaça grass under conditions of implantation of a silvopastoral system with eucalyptus and in monoculture.

\section{MATERIAL AND METHODS}

The experiment was conducted at the Federal University of Tocantins Campus de Araguaína, at the School of Veterinary Medicine and Animal Science, at latitude, longitude and altitude of $07^{\circ} 05^{\prime} 43^{\prime} ' \mathrm{~S}, 48^{\circ} 12^{\prime} 13^{\prime}$ ' $\mathrm{W}$ and $226 \mathrm{~m}$, respectively. The climate of the region, according to the Köppen classification (1948), is Aw (hot and humid). The experiment was conducted in the rainy seasons of the agricultural years 2016/2017 and 2017/2018. The meteorological data of the experimental periods were recorded in the meteorological station, located $900 \mathrm{~m}$ from the experimental area (Table 1). 
Table 1: Maximum and minimum temperatures, relative humidity and rainfall in the experimental period.

\begin{tabular}{lllll}
\hline Months & Max temperature $\left({ }^{\mathbf{0}} \mathbf{C}\right)$ & Min temperature $\left({ }^{\mathbf{0}} \mathbf{C}\right)$ & Humidity (\%) & Rainfall $(\mathbf{m m})$ \\
\hline December 2016 & 25.9 & 24.8 & 83.5 & 99.4 \\
January 2017 & 25.4 & 24.3 & 86.0 & 289.0 \\
February 2017 & 25.3 & 24.3 & 87.4 & 348.0 \\
March 2017 & 25.9 & 24.7 & 86.6 & 235.2 \\
April & 26.1 & 24.8 & 86.1 & 204.0 \\
\hline Average year 1 & 27.7 & 24.5 & 85.9 & 235.0 \\
\hline December 2017 & 25.1 & 24.4 & 86.3 & 64.8 \\
January 2018 & 25.2 & 24.0 & 85.9 & 251.4 \\
February 2018 & 25.3 & 24.2 & 87.3 & 255.2 \\
March 2018 & 25.8 & 24.7 & 85.9 & 341.8 \\
\hline Average year 2 & 25.3 & 24.3 & 86.3 & 228.3 \\
\hline
\end{tabular}

Source: INMET, 2019.

The soil of the area was a typical Quartzarênico Órtico Neosol (EMBRAPA, 2014). The studied area was 1.0 ha, divided into two systems, the first was a monoculture of Megathyrsus maximus cv. Mombaça with 0.25 ha, and the second, a silvopastoral, system intercropping eucalyptus (Eucalyptus urograndis) with Mombaça grass, with an area of 0.75 ha in the Amazon/Cerrado ecotone.

The soil was sampled at a depth of 0 to $20 \mathrm{~cm}$ in November of each year evaluated, performing chemical analysis (Table 2) according to the methodology proposed by EMBRAPA (2013).

Table 2: Soil chemical characteristics in the $0-20 \mathrm{~cm}$ deep layer of the experimental area

\begin{tabular}{|c|c|c|c|c|c|c|c|c|c|c|c|}
\hline \multirow{2}{*}{ System } & pH & OM & $\mathbf{P}$ & $\mathbf{K}^{+}$ & $\mathrm{Ca}^{++}$ & $\mathbf{M g}^{++}$ & $\mathbf{H}+\mathbf{A l}$ & $\mathbf{A l}^{++}$ & \multirow{2}{*}{$\begin{array}{r}\text { SB } \\
\%\end{array}$} & \multirow{2}{*}{$\begin{array}{l}\text { CEC } \\
\text { Cmolc.dm }^{-3}\end{array}$} & \multirow{2}{*}{$\begin{array}{l}\mathrm{V} \\
\%\end{array}$} \\
\hline & $\mathrm{Cacl}_{2}$ & g.kg-1 & mg.dm ${ }^{-3}$ & \multicolumn{5}{|c|}{ Cmolc.dm ${ }^{-3}-$} & & & \\
\hline \multicolumn{12}{|l|}{ Year (2016) } \\
\hline Mono & 4.28 & 1.13 & 1.42 & 0.12 & 1.55 & 0.55 & 5.17 & 0.33 & 2.22 & 7.72 & 28.75 \\
\hline Ssp & 4.58 & 1.23 & 1.42 & 0.14 & 1.45 & 0.65 & 5.19 & 0.35 & 2.24 & 7.78 & 28.79 \\
\hline \multicolumn{12}{|l|}{ Year (2017) } \\
\hline Mono & 4.58 & 1.54 & 2.70 & 0.08 & 1.14 & 0.38 & 4.36 & 0.22 & 1.60 & 6.18 & 25.88 \\
\hline Ssp & 4.80 & 1.54 & 2.74 & 0.08 & 1.17 & 0.40 & 4.34 & 0.25 & 1.65 & 6.24 & 26.44 \\
\hline \multicolumn{12}{|l|}{ Year (2018) } \\
\hline Mono & 4.10 & 2.90 & 1.47 & 0.10 & 0.91 & 0.91 & 3.38 & 0.50 & 1.52 & 5.4 & 28.14 \\
\hline Ssp & 4.08 & 2.43 & 1.66 & 0.10 & 0.81 & 0.81 & 3.34 & 0.30 & 1.21 & 4.85 & 24.94 \\
\hline
\end{tabular}

Mono: monoculture of Megathyrsus maximus cv. Mombaça; Ssp: Silvopastoral system; pH: potential of hydrogen; $\mathrm{CaCl}_{2}$ : Calcium chloride; OM: Organic matter; P: phosphorus in the soil in milligrams per cubic decimeter using the Mehlich method ${ }^{1}$; K: Potassium in milligrams per cubic decimeter using the Mehlich method $^{1}$; Ca: Calcium; Mg: Magnesium; $\mathrm{H}+\mathrm{Al}$ : hydrogen plus aluminum; Al: Aluminum; SB: sum of bases; $\mathrm{V}$ : Base saturation, CEC: Total cation exchange capacity; cmolc. $\mathrm{dm}^{-3}$ : centimol of charge per cubic decimeter.

Two months before implementing the experiment, liming was performed to correct the soil, and dolomitic limestone with $80 \%$ PRNT was incorporated with the aid of a plow harrow. Application of limestone in Quartzarênico Neosol is justified because this soil is a sediment with high depth and predominance of medium and coarse sand, the concentration of organic matter is very low, and mineralization is very intense due to the characteristics of the region (CARNEIRO et al., 2009). Allied to this, the implanted crops have their extraction particularities, such as eucalyptus with its rapid development and nutritional 
requirements, and Mombaça due to the large number of cycles, demand a lot from the soil. And the soil due to the very low load takes the characteristics mentioned and these pastures after each cycle are exported to other sites and leading to an annual decrease in CEC.

In the silvopastoral system, 350 seedlings of E. urograndis were planted on $15 / 12 / 2016$, in pits $40 \mathrm{~cm}$ deep, in the East-West direction, allowing greater light incidence in the understory, with $9.0 \mathrm{~m}$ spacing between double rows, $2 \mathrm{~m}$ between plants, and $3 \mathrm{~m}$ between single rows. Nutrition gel was used to plant eucalyptus, $300 \mathrm{~mL}$ per plant. On 18/12/2016, Mombaça grass was sown broadcast using $4.5 \mathrm{~kg}$ pure viable seeds per hectare, in both systems.

After forage establishment, in which it reached 3 to 4 leaves per tiller, in March 2017 the standardization cut was performed.

The design used was completely randomized (DIC), although unusual, it was used because the experimental area of Quartzarênico Neosol was homogeneous in depth, slope. The DIC with repeated measures over time agricultural years (2016/2017 and 2017/2018), the main plot arranged in a $2 \times 4$ factorial arrangement, with two cultivation systems (monoculture and silvopastoral) and four levels of phosphorus $(0 ; 50 ; 100 ; 200 \mathrm{~kg}$ $\mathrm{P}_{2} \mathrm{O}_{5}$ ha $^{-1}$ year $\left.^{-1}\right)$, with three repetitions per plot, in three cycles per experimental period.

The source of phosphorus was single superphosphate, broadcast applied by hand only once a year. At the beginning of each regrowth period, nitrogen $(\mathrm{N})$ and potassium $\left(\mathrm{K}_{2} \mathrm{O}\right)$ fertilization was carried out with $150 \mathrm{~kg} \mathrm{ha}^{-1}$ of the formula $30: 00: 30(30 \% \mathrm{~N}, 0 \%$ of ??? and $30 \%$ $\mathrm{K}_{2} \mathrm{O}$ ) per cycle, with 21 rest days per cycle. This fertilization is in accordance with the recommendation for management systems of medium technological level and for a demanding forage like Mombaça grass (CFSEMG, 1999). In the following year 2017/2018, the standardization cut and the phosphate, nitrogen and potassium fertilization were repeated.

Grass height was monitored and controlled every seven days; canopy height was measured at 30 points at random, using a graduated ruler (SANTOS et al., 2011).

Evaluations of morphogenic and structural characteristics were studied in relation to the growth and death dynamics of the plants measured at the level of tiller individually, using the technique of marked tillers, according to Davies (1993), in which the readings started, three days after fertilization, every 7 days. Leaf lengths, expanding and expanded, senescent parts, as well as the length of the stems (height from the ground to the last expanded leaf) were measured and tillers counted by area (tiller. $\mathrm{m}^{-2}$ ) using a frame $0.15 \mathrm{~m} \times 1.00 \mathrm{~m}\left(0.15 \mathrm{~m}^{2}\right)$. In addition, new leaves that appeared during each cycle were recorded. From this information, morphogenic variables were calculated: leaf appearance rate (TApF, leaf. Tiller ${ }^{-1}$. Day ${ }^{-1}$ ); leaf elongation rate (TAlF, cm leaf. Tiller ${ }^{-1}$. Day $^{-1}$ ); phyllochron (days. Leaf ${ }^{-1}$. Tiller ${ }^{-1}$ ); stem elongation rate (TAlC, $\mathrm{cm}$ stem. Tiller ${ }^{-1}$. Day $^{-1}$ ).

Leaf area index (IAF) was estimated from a leaf sub-sample. Segments with $10 \mathrm{~cm}$ were cut, and the sum of the average width of all segments was multiplied by $10 \mathrm{~cm}$, thus estimating the leaf area of the subsample (IAF, $\mathrm{m}^{2}$ leaf $/ \mathrm{m}^{2}$ soil) according to Alexandrino et al. (2005).

For the evaluation of the structural characteristics, we evaluated tiller 
population density (DPP); leaf/stem ratio, percentage of leaves and stems in the total dry mass; crop growth rate (TCC), which was estimated by dividing the mass of green forage by the length of the rest period.

The statistical model adopted was:

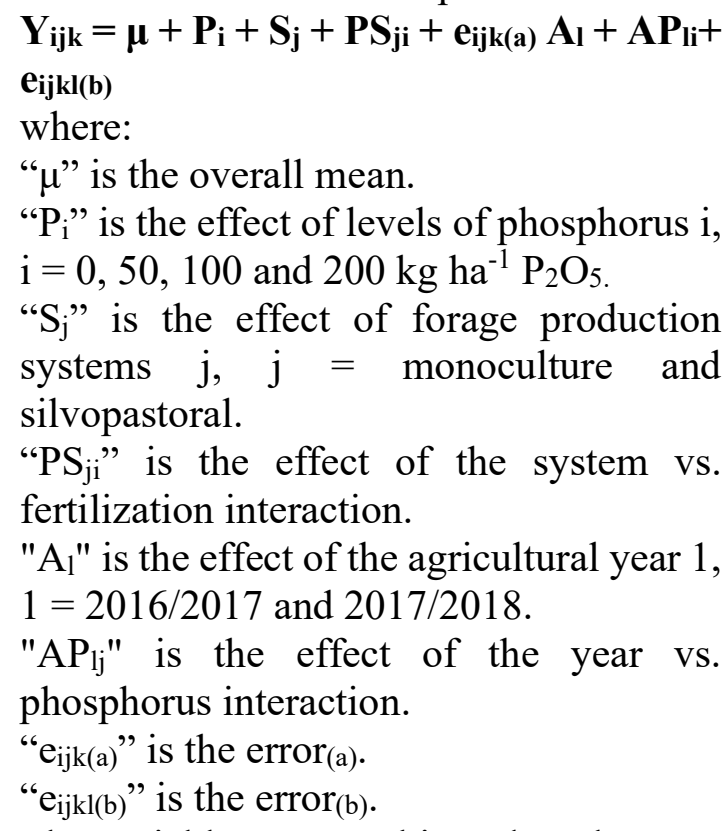

The variables were subjected to the tests of normality (SHAPIRO-WILK, 1965) and homoscedasticity (COCHRAN, 1941). For variables with normal data distribution and with homogeneous variances, analysis of variance was applied, followed by an F-test on ANOVA parameters. For the comparison of the years and systems studied, Student's t-test was run for comparison of means, and for the levels of phosphorus, regression analysis was carried out observing the linear, quadratic and deviation from linearity effects, adopting the significance of $5 \%$ for probability of type I error.

\section{RESULTS AND DISCUSSION}

In general, factors tested, such as: phosphorus fertilization, production system and year (implantation and following year) of the study, showed significant influence, altering the development of Mombaça grass, reflecting on the morphogenic and structural characteristics. There was no interaction between phosphorus fertilization and the production system analyzed, only in relation to the variables: (TAPF), (TALF), (TALC), phyllochron and (DVF), with $\mathrm{P}>0.05$ (Table 3 ).

Phosphorus fertilization provided greater root development, which reflected significantly in the development of the aerial part, providing a positive correlation between TAPF and TALF (0.70), thus enabling greater growth of the leaf fraction (OLIVEIRA et al., 2014).

Torres et al. (2016) evaluated phosphorus doses in the early development and forage production of Megathyrsus maximus cultivars, and found a quadratic effect for doses from 48 to $50 \mathrm{~kg} \mathrm{ha}^{-1}$, with maximum points of $56 \mathrm{~kg} \mathrm{ha}^{-1}$; these authors still infer that doses above the maximum point decrease leaf elongation, as the plant responds positively up to 56 kg.ha- ${ }^{-1}$ year $^{-1} \mathrm{P}$, and from that point on, there is a drop in production, thus interrupting the leaf elongation and growth, observations that corroborate the present study at doses greater than $140 \mathrm{~kg}$ ha $^{-1}$.year ${ }^{-1} \mathrm{P}_{2} \mathrm{O}_{5}$.

TALC was affected by the production system, in which the silvopastoral system presented a higher TALC than the monoculture system. Such results occurred, possibly, due to the competition for light, space and nutrients among the young tillers; they tend to increase the elongation of stems to achieve a greater exposure to light, in addition, the stem elongation was greater at the reproductive phase than at the vegetative phase, since the transition from vegetative to 
reproductive development is marked by an increase in the frequency of cell divisions within the central zone of the apical meristem of the stem, resulting in stem elongation (TAIZ \& ZEIGER, 2009).

Table 3. Morphogenic characteristics of Mombaça grass under the effect of phosphorus fertilization in cultivation systems

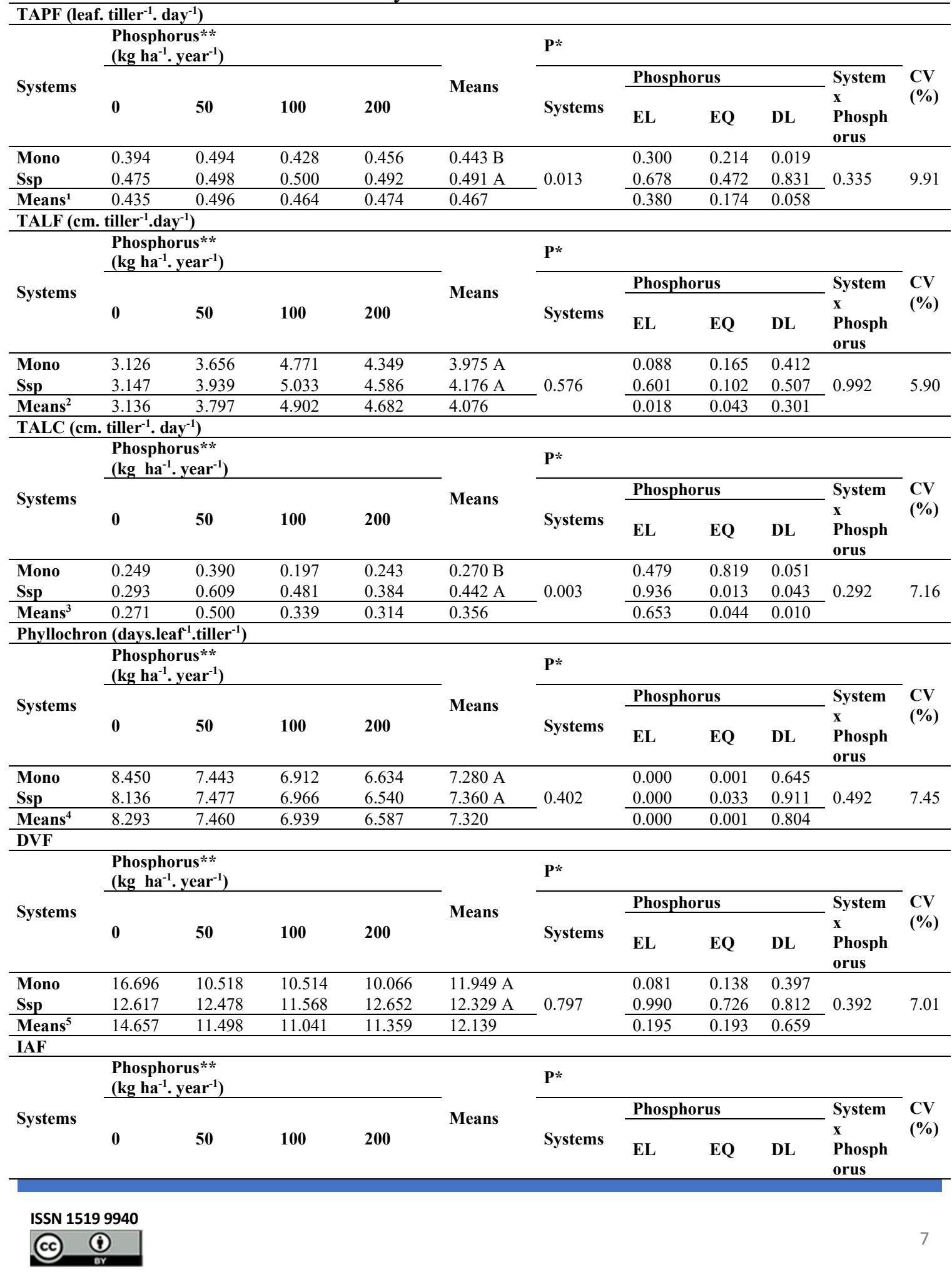




\begin{tabular}{|c|c|c|c|c|c|c|c|c|c|c|c|}
\hline Mono & $3.326 \mathrm{~B}$ & $3.500 \mathrm{~B}$ & $5.340 \mathrm{~B}$ & $3.620 \mathrm{~B}$ & 3.946 & \multirow{3}{*}{$<0.001$} & $<0.001$ & $\begin{array}{l}<0.00 \\
1\end{array}$ & 0.234 & \multirow{3}{*}{0.001} & \multirow{3}{*}{6.65} \\
\hline Ssp & $5.176 \mathrm{~A}$ & $5.426 \mathrm{~A}$ & $6.633 \mathrm{~A}$ & $5.623 \mathrm{~A}$ & 5.714 & & $<0.001$ & $\begin{array}{l}<0.00 \\
1\end{array}$ & 0.187 & & \\
\hline Means $^{6}$ & 4.251 & 4.463 & 5.986 & 4.621 & 4.830 & & $<0.001$ & $\begin{array}{l}<0.00 \\
1\end{array}$ & 0.210 & & \\
\hline
\end{tabular}

Mono: monoculture of Megathyrsus maximus $c v$. Mombaça; Ssp: Silvopastoral system; P*: Probability of type I error; Phosphorus **: $\mathrm{P}_{2} \mathrm{O}_{5}$ doses; TAPF: tiller leaf appearance rate. Tiller. Day ${ }^{-1}$; TAPF: leaf appearance rate cm leaf. Tiller. Day ${ }^{-1}$; TAPF: leaf appearance rate cm stem. Tiller ${ }^{-1}$. Day ${ }^{-1}$; DVF: leaf life days; IAF: Leaf area index; EL: Linear effect; EQ: Quadratic effect; DL: Deviation from linearity; CV: coefficient of variation; mean values followed by different uppercase letters, in the same column, or lowercase letters, in the same row, are significantly different $(\mathrm{P}<0.05)$ by Student's t-test. Equations: $1-\hat{\mathrm{y}}=0.467 ; 2-\hat{\mathrm{y}}=3.028534+0.025760 \mathrm{X}-$ $0.000092 X^{2}\left(R^{2}=92.00 \%\right) ; 3-\hat{y}=0.356 ; 4-\hat{y}=8.298573-0.018905 X+0.0000514 X^{2}\left(R^{2} 99.97\right) ; 5-\hat{y}=12.136$.

The increase in phosphorus fertilization provides greater productivity of the dry mass of the aerial part of Mombaça grass and the rapid renewal of plant tissues, which was demonstrated by phyllochron, which responded at the level of $183.54 \mathrm{~kg}$ $\mathrm{ha}^{-1}$.year ${ }^{-1} \mathrm{P}_{2} \mathrm{O}_{5}$ providing less time for the appearance of the set of Mombaça grass leaves. Costa et al. (2016) verified a quadratic relationship and the maximum estimated value with the application of $91.3 \mathrm{~kg} \quad \mathrm{P}_{2} \mathrm{O}_{5} \cdot \mathrm{ha}^{-1}$, confirming the efficiency observed in the following work, that the application of phosphorus results in good leaf production in grasses.

There was a negative correlation between the phyllochron and DVF (-0.22), this relationship indicates the mechanics of pasture growth related to the condition of the medium, which if favorable, the expression is maximum of its genetic potential, responding to the high fertility of the soil, due to the fertilization used, allowing the plant a greater speed in leaf replacement. The lower the phyllochron, the more efficient the grass is at intercepting and converting light energy into leaf tissue, since this variable increases with plant age, due to the longer time for the leaf to travel the distance between the apical meristem and the end of the pseudostem formed by the sheaths of older leaves (LUNA et al., 2012).

Leaves have a limited life span, which is determined by genetic traits, which are influenced by environmental factors and management practices (LEMAIRE et al., 2008). As the present study shows similarity in the characteristics (nutritional, environmental and management used) of the production systems, there was no effect of the tested parameters for DVF.

The action of phosphorus fertilization in improving soil fertility on leaf elongation, leaf length and tiller population density is directly expressed on the IAF of the pasture, which can be demonstrated by the positive correlation of IAF with other variables, such as TAPF, TALF and DPP, resulting in greater forage production (PONTES et al., 2010). IAF values between 3.4 and 4.8 were reported by Duarte et al. (2019), who analyzed tropical grass managed under intermittent stocking, fertilized with phosphorus sources with different solubilities, combined or not with nitrogen; the authors also report that the higher amounts of $\mathrm{P}$ in the soil enable greater growth and accumulation of leaves, which resulted in increased IAF, a fact observed in the present study.

There was an effect $(\mathrm{P}<0.05)$ of phosphorus fertilization and the production system on DPP and TCC (Table 4). There was a quadratic effect of phosphorus fertilization on DPP, with the maximum point for this parameter being 132.80 and $119.40 \mathrm{~kg} \mathrm{ha}^{-1}$. year ${ }^{-1} \mathrm{P}_{2} \mathrm{O}_{5}$ for monoculture and Ssp, respectively. 
Table 4. Structural characteristics of Mombaça grass under the effect of phosphorus fertilization in cultivation systems

\begin{tabular}{|c|c|c|c|c|c|c|c|c|c|c|c|}
\hline \multicolumn{12}{|c|}{ DPP (tillers per $\mathbf{m}^{2}$ ) } \\
\hline \multirow{3}{*}{ Systems } & \multicolumn{4}{|c|}{$\begin{array}{l}\text { Phosphorus** } \\
\left(\text { kg ha }^{-1} \text { year }^{-1}\right)\end{array}$} & \multirow{3}{*}{ Means } & \multicolumn{5}{|l|}{$\mathbf{P} *$} & \multirow{3}{*}{$\begin{array}{l}\text { CV } \\
(\%)\end{array}$} \\
\hline & \multirow[b]{2}{*}{$\mathbf{0}$} & \multirow[b]{2}{*}{50} & \multirow[b]{2}{*}{100} & \multirow[b]{2}{*}{200} & & \multirow[b]{2}{*}{ Systems } & \multicolumn{3}{|l|}{ Phosphorus } & \multirow{2}{*}{$\begin{array}{l}\text { System } \\
\text { x } \\
\text { Phosph } \\
\text { orus } \\
\end{array}$} & \\
\hline & & & & & & & EL & EQ & DL & & \\
\hline Mono $^{1}$ & $30.795 \mathrm{~A}$ & $35.964 \mathrm{~B}$ & 64.879A & $49.428 \mathrm{~A} \quad 4$ & 45.267 & \multirow{3}{*}{0.344} & $<0.001$ & $<0.001$ & 0.209 & \multirow{3}{*}{$<0.001$} & \multirow{3}{*}{8.15} \\
\hline Ssp $^{2}$ & $30.956 \mathrm{~A}$ & $43.362 \mathrm{~A}$ & $60.864 \mathrm{~B}$ & 43.501B 4 & 44.671 & & $<0.001$ & $<0.001$ & 0.313 & & \\
\hline Means & 30.875 & 39.663 & 62.872 & 46.464 & 44.969 & & $<0.001$ & $<0.001$ & 0.645 & & \\
\hline \multicolumn{12}{|c|}{ TCC $\left(\mathrm{Kg} \mathrm{ha}^{-1} \cdot \mathrm{day}^{-1}\right)$} \\
\hline \multirow{3}{*}{ Systems } & \multicolumn{4}{|c|}{$\begin{array}{l}\text { Phosphorus } * * \\
\left(\text { kg ha }^{-1} \text { year }^{-1}\right)\end{array}$} & \multirow{3}{*}{ Means } & \multicolumn{4}{|l|}{$P^{*}$} & & \\
\hline & \multirow{2}{*}{$\mathbf{0}$} & \multirow{2}{*}{50} & \multirow{2}{*}{100} & \multirow{2}{*}{200} & & \multirow{2}{*}{ Systems } & \multicolumn{3}{|c|}{ Phosphorus } & \multirow{2}{*}{$\begin{array}{l}\text { System } \\
\text { x } \\
\text { Phospho } \\
\end{array}$} & \multirow[t]{2}{*}{ (\%) } \\
\hline & & & & & & & EL & EQ & DL & & \\
\hline Mono $^{2}$ & $124.7 \mathrm{~A}$ & 146.760B & $262.504 \mathrm{~A}$ & $202.091 \mathrm{~A}$ & A 184.033 & & $<0.001$ & $<0.001$ & 0.087 & & \\
\hline $\mathrm{Ssp}^{3}$ & $126.3 \mathrm{~A}$ & $176.973 \mathrm{~A}$ & $247.259 \mathrm{~B}$ & $177.934 \mathrm{~B}$ & B $\quad 182.140$ & 0.441 & $<0.001$ & $<0.001$ & 0.067 & $<0.001$ & 7.85 \\
\hline Means & 125.584 & 161.867 & 254.882 & 190.013 & 183.086 & & $<0.001$ & $<0.001$ & 0.245 & & \\
\hline \multicolumn{12}{|c|}{ Leaf: stem ratio } \\
\hline \multirow{3}{*}{ Systems } & $\begin{array}{l}\text { Phospho } \\
\left(\mathrm{kg} \mathrm{ha}^{-1} \mathrm{y}\right.\end{array}$ & $\begin{array}{l}\text { rus }^{* * *} \\
\left.\text { ear }^{-1}\right)\end{array}$ & & & & P* & & & & & \\
\hline & & & & & Means & & Phosphorus & & & System & CV \\
\hline & $\mathbf{0}$ & 50 & 100 & 200 & & Systems & $\mathbf{E L}$ & EQ & DL & $\begin{array}{l}\text { x } \\
\text { Phosph } \\
\text { orus }\end{array}$ & \\
\hline Mono & 0.721 & 0.813 & 0.831 & 0.715 & $0.774 \mathrm{~B}$ & & 0.096 & $<0.001$ & 0.507 & & \\
\hline Ssp & 0.864 & 0.929 & 0.925 & 0.903 & $0.905 \mathrm{~A}$ & $<0.001$ & 0.362 & 0.086 & 0.068 & 0.081 & 5.44 \\
\hline Means $^{\text {s4 }}$ & 0.792 & 0.871 & 0.878 & 0.809 & 0.825 & & 0.564 & $<0.001$ & 0.110 & & \\
\hline $\begin{array}{l}\text { Mono: mo } \\
\mathrm{P}_{2} \mathrm{O}_{5} \text { doses } \\
\text { effect; DL } \\
\text { same row, } \\
\% \text { ); } 2 \text { - } \hat{y}= \\
0.825\end{array}$ & $\begin{array}{l}\text { culture of } \\
\text { PP: tiller } 1 \\
\text { eviation fr } \\
\text { significal } \\
9.142671\end{array}$ & $\begin{array}{l}\text { Megathyrsu } \\
\text { population } \\
\text { om linearity } \\
\text { ntly differen } \\
+1.951163\end{array}$ & $\begin{array}{l}\text { us maximus } \\
\text { density per } \mathrm{n} \\
\mathrm{y} \text {; mean valu } \\
\text { nt }(\mathrm{P}<0.05) \\
\mathrm{X}-0.007302\end{array}$ & $\begin{array}{l}c v \text {. Mombaç, } \\
\mathrm{m}^{2} \text {; TCC: cro } \\
\text { les followed } \\
\text { by Student's } \\
2 \mathrm{X}^{2}\left(\mathrm{R}^{2}=73\right.\end{array}$ & $\begin{array}{l}\text { ça; Ssp: Si } \\
\text { op growth } \\
\text { by differe } \\
\text { s t-test. Eq } \\
3.77 \%) ; 3\end{array}$ & $\begin{array}{l}\text { pastoral sys } \\
\text { e; CV: coef } \\
\text { uppercase l } \\
\text { ions: } 1-\hat{y} \\
=119.0565\end{array}$ & $\begin{array}{l}\text { tem; } P^{*} \text { : Pro } \\
\text { ficient of vari } \\
\text { etters, in the } s \\
=26.853941 \\
45+1.96397\end{array}$ & $\begin{array}{l}\text { bability of } \\
\text { iation; EL: } \\
\text { same colun } \\
+0.48342 \\
4 \mathrm{X}-0.00\end{array}$ & $\begin{array}{l}\text { pe I err } \\
\text { inear eff } \\
\text { or lowe } \\
-0.001 \\
87 \mathrm{X}^{2}\left(\mathrm{R}^{2}\right.\end{array}$ & $\begin{array}{l}\text { r; Phospho } \\
\text { ct; EQ: Qu } \\
\text { case letters } \\
20 \mathrm{X}^{2}\left(\mathrm{R}^{2}\right. \\
=91.10 \%)\end{array}$ & $\begin{array}{l}\text { us **: } \\
\text { adratic } \\
\text { in the } \\
72.80 \\
4-\hat{y}=\end{array}$ \\
\hline
\end{tabular}

From these applied phosphorus levels, there was a decrease in tiller population for both systems. Tillering is dependent on internal and external conditions to the plant, being regulated mainly by the genotype, hormonal balance, flowering, light, temperature, photoperiod, water, mineral nutrition, mainly phosphorus, since it acts directly on grass tillering (LANGER, 1972).

Similar values of tiller production were found by Torres et al. (2016), who studied phosphorus at the initial development and forage production of cultivars of Megathyrsus maximus, with higher tillering of Mombaça grass at a dose of $60 \mathrm{~kg} \mathrm{P}_{2} \mathrm{O}_{5} \cdot \mathrm{ha}^{-1}$. Dias et al. (2015) evaluated the production of Brachiaria brizantha cv. BRS Piatã submitted to sources of phosphorus, and obtained greater response in tiller density when a high level of soluble sources was applied. These results are possibly explained by the intense meristematic activity promoted by the supply of phosphorus at the initial stage of forage regrowth.

Fertilization influenced the TCC, with a quadratic effect of 133.60 and 118.50 ha $^{-}$ ${ }^{1}$.year ${ }^{-1} \mathrm{P}_{2} \mathrm{O}_{5}$ for monoculture and Ssp, respectively; from this plateau a decrease in the growth of the culture was found, 
independent of the production system. There was a positive correlation between DPP and TCC (0.99) in relation to the increase in phosphate fertilization, which reflect increases in the rates of leaf elongation, leaf appearance and tiller production. This occurred due to greater tissue renewal, associated with the main effect of the nutrient in increasing the rate of cell production and tillering, thus enabling a higher forage growth rate (ROMA et al., 2012).

The absence of interactions in the present study for the leaf: stem ratio can be related to the fact that the cut management was the same, generating similarity in the responses found. Nevertheless, it is inferred that phosphorus fertilization was able to provide increases in forage productivity in the implantation and establishment phase, generating positive gains in the leaf fraction, being observed that the SSP obtained higher TALF and TAPF, which increased this fraction (leaf) in relation to the stem, generating a high-quality forage. The largest leaf fraction in the forage improves the nutritional value of the grass, as it is the fraction most selected by animals; TALF is a determining characteristic for productive genotypes, even when they are under different management conditions (LARA; PEDREIRA, 2011).

There were no interactions of phosphorus levels with the year of implantation and the following year for the variables: TAPF, TALF, TALC; Phyllochron, DVF, DPP, TCC, leaf: stem ratio, with $\mathrm{P}<0.05$ (Tables 5 and 6). This higher TAPF and TALF in the second year is possibly because the grass metabolism is more efficient in capturing photoassimilates in the year following implantation, as well as, better root development, which allowed the emergence of more tillers and new leaves (CARNEIRO et al., 2017). 
Table 5. Morphogenic characteristics of Mombaçaa grass under the effect of phosphorus fertilization in the experimental years.

TAPF (leaf. tiller ${ }^{-1}$. day $^{-1}$ )

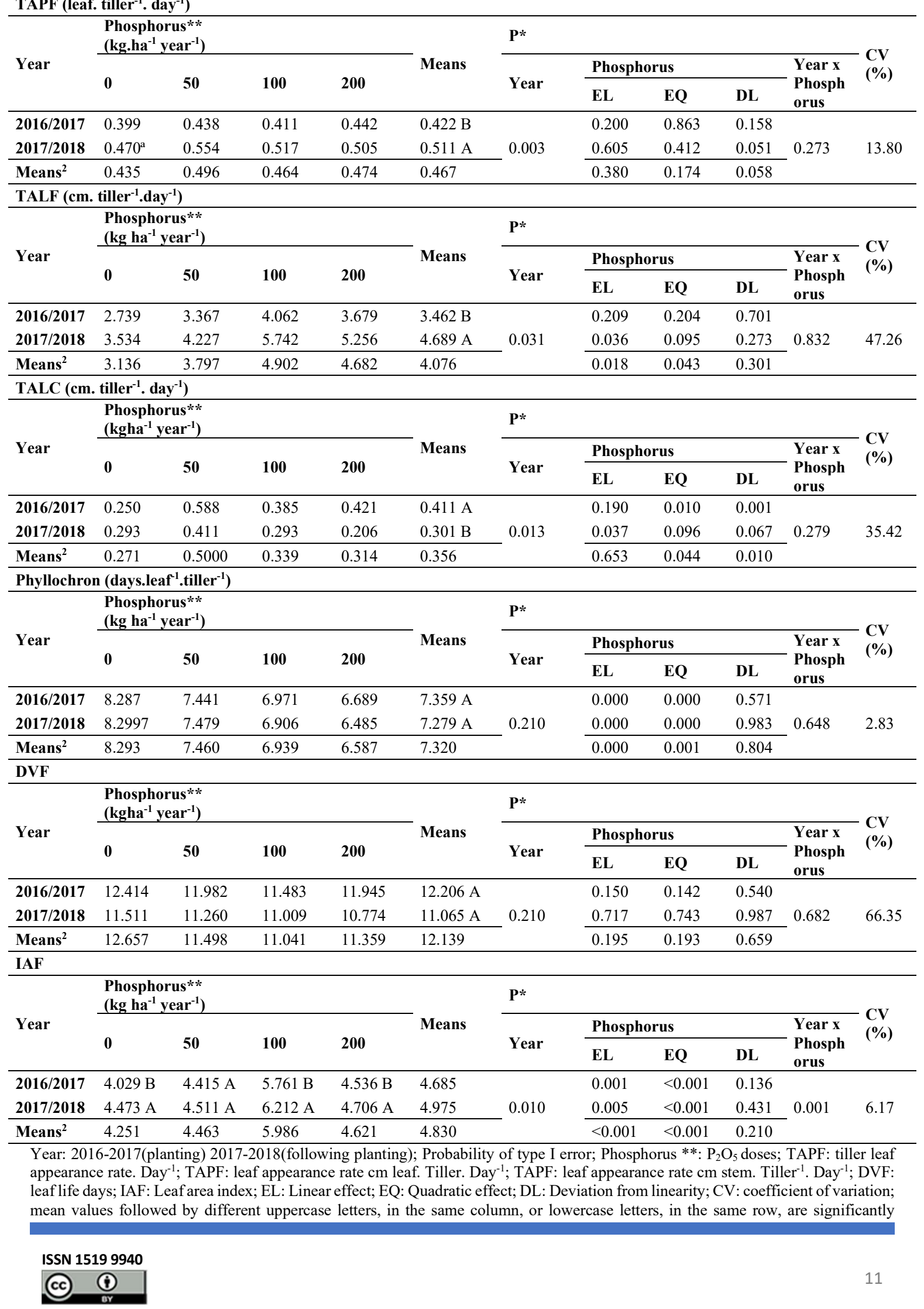


different $(P<0.05)$ by Student's t-test. Equations: $1-\hat{y}=0.467 .2-\hat{y}=3.028534+0.025760 X-0.000092 X^{2}\left(R^{2}=92.00 \%\right) ; 3-\hat{y}=$ $\left.0.356 ; 4-\hat{y}=8.298573-0.018905 X+0.0000514 X^{2}\left(R^{2} 99.97\right) ; 5--\hat{y}=12.136 ; \%\right) ; 6-\hat{y}=3.843916+0.027157 X-0.00012 X^{2}\left(R^{2}\right.$ $=75.05 \%) ; 7-\hat{y}=4.203824+0.026413 X-0.000117 X^{2}\left(R^{2}=56.98 \%\right)$.

There was a difference $(\mathrm{P}<0.05)$ for TALC, the year 2016/2017 presented a higher value for this variable, possibly because the plant is expressing its genetic potential to the maximum and the shading at the base of the clump allows an increase in TALC because when shading occurs on new tillers, they tend to increase stem elongation, in search of light and the emergence of new leaves, since the plant seeks to intensify the development of existing tillers at the expense of new tillers, thus increasing TALC (SILVEIRA JUNIOR et al., 2017).

There was no significant difference ( $p$ $<0.05$ ) in phyllohron between years, however, there was a quadratic effect for the fertilization levels in the years evaluated $181.59 \mathrm{~kg} \mathrm{ha}^{-1}$ year ${ }^{-1} \mathrm{P}_{2} \mathrm{O}_{5}$.

There was no effect of phosphorus levels on DVF in the years. This can be justified because the planted grass shows similarity in the cultural treatments and cut management adopted for the experimental years. Leaf life span consists of a limited process and once reached its final size, leaves remain in the tillers for a certain period, enter senescence and die; this growth dynamics is an important characteristic and can be used as management tool, functioning as an indicator for determining grazing intensity and the maximum resting time between grazing (MARTUSCELLO et al. 2006).

Phosphorus fertilizer applied in the experimental years favored a greater IAF, a greater response of the plant, presenting a physiological development superior to the initial year, with a larger volume of root, leaves and stems, being the result of this interaction expressed in the present study (Table 5). The importance of nutritional replacement via fertilization is reported by Duarte et al. (2016), since its absence or even its inefficiency can lead the plant to use the phosphorus available in the solution only for maintenance, which can stop the emergence of tillers, new leaves and interrupting their development and production. In the present experiment, since phosphorus is replaced each year, greater production occurred in the year following implantation.

The structural characteristics did not show any interaction between the years of experimental evaluation and the fertilization used, due to nutritional replacement in cycles and annually, provided similarity in the response of the grass in the years (Table 6).

The similarity of values found in DPP, TCC and leaf: stem ratio can be verified in Dias et al. (2015), who, when evaluating the production of Piatã palisadegrass subjected to different sources of phosphorus, obtained a greater response in tiller density, when increasing levels of soluble phosphorus fertilizers were applied. These authors argue that this occurred due to the intense meristematic activity promoted by the supply of phosphorus at the early regrowth phase of the forage, exactly as in the present study, in which there was mineral replacement via phosphorus fertilization at the beginning of each year, allowing forage response in the study years. The same behavior can be observed for TCC, which responds to DPP gains and, consequently, interferes with the leaf: stem ratio, resulting in a forage with a higher proportion of 
leaves, of good quality and high production over the years.

Table 6. Structural characteristics of Mombaça grass under the effect of phosphorus fertilization in the experimental years.

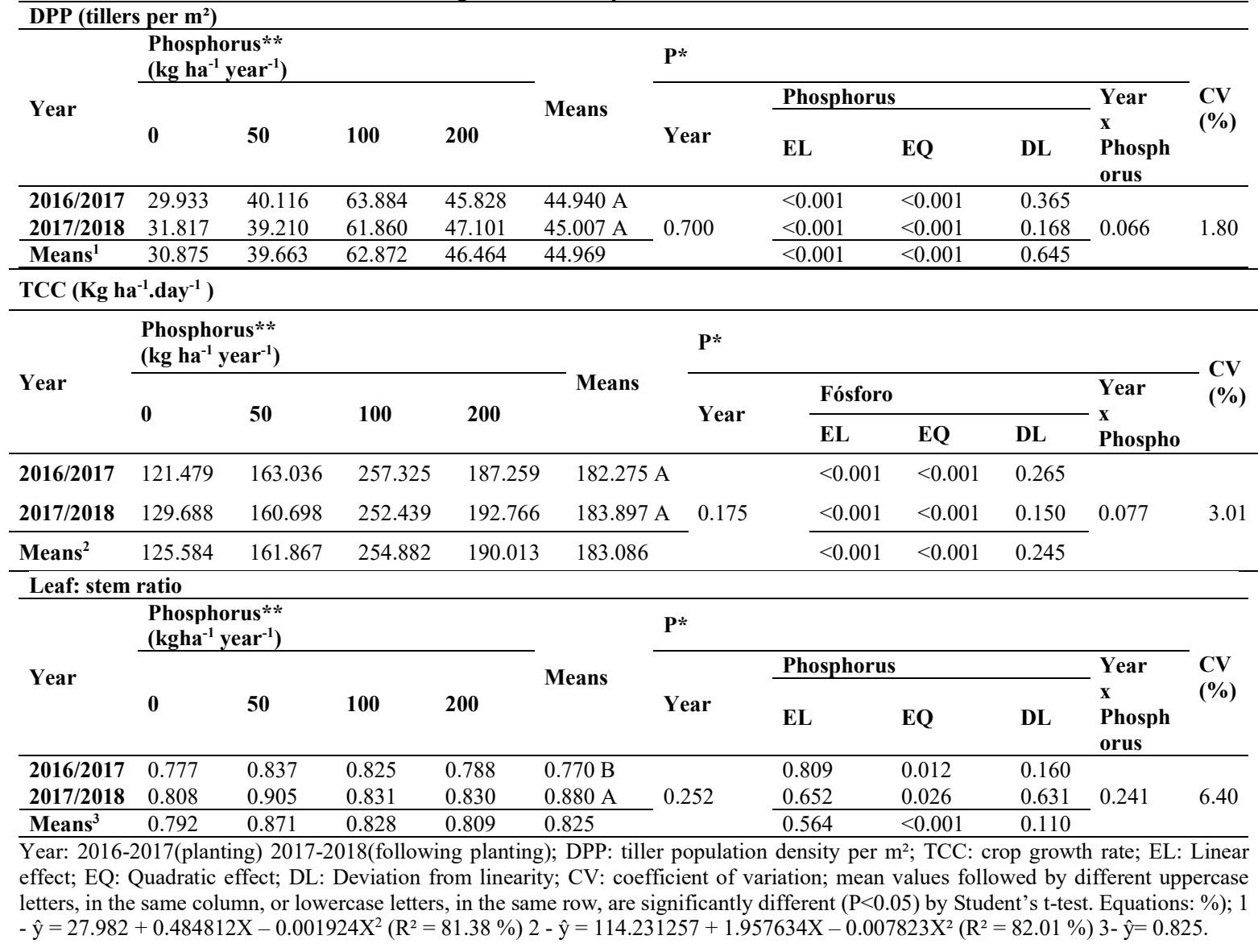

Thus, it can be concluded that phosphorus fertilization used for implantation, moment of highest requirement for the nutrient, favored the morphogenic and structural modifications in the plant, which reflected in the development of the forage, increasing the crop growth rate, the leaf appearance rate, leaf and stem elongation rates.

\section{ACKNOWLEDGEMENTS}

This work was carried out with the financial assistance from the Coordination for the Improvement of Higher Education Personnel - CAPES and the Research Productivity Scholarship Program of the Federal University of Tocantins - UFT.

\section{REFERENCES}

ALEXANDRINO, E.; NASCIMENTO JUNIOR, D.; REGAZZI, A. Características morfogênicas e estruturais da Brachiaria brizanthacv. 
Marandu submetida a diferentes doses de nitrogênio e freqüências de cortes. Acta Scientiarum Agronomy, v.27, p.17 24, 2005.

CARVALHO, P. C. F.; MORAES, A.; PONTES, L. S.; ANGHINONI, I.; SULC, R. M.; BATELLO, C. Definições e terminologias para Sistema Integrado de Produção Agropecuária. Revista Ciência Agronômica, v. 45, n. 5, p. 1040-1046, 2014.

CARNEIRO, J. S. S; SILVA, P. S. S; SANTOS, A. C. M; FREITAS, G. A; SILVA, R. R. Resposta do capim Mombaça sob efeito de fontes e doses de fósforo na adubação de formação. Journal of bioenergy and food science, v.4, n.1, p.12-25, 2017.

CARNEIRO, M.A.C.; SOUZA, E.D.; REIS, E.F.; PEREIRA, H.S.; AZEVEDO, W.R. Atributos físicos, químicos e biológicos de solo de Cerrado sob diferentes sistemas de uso e manejo. Revista Brasileira Ciência do Solo, 33:147-157, 2009.

CFSEMG - Comissão de Fertilidade do Solo do Estado de Minas Gerais. Recomendações para o uso de corretivos e fertilizantes em Minas Gerais. $5^{\text {a }}$ aproximação. Viçosa: DFSEMG, 1999. 359 p.

COCHRAN, W.G. The distribution of the largest of a set of estimated variances as a fraction of their total. Annals of Human Genetics, v.11, n.1, p.47-52, 1941.

COSTA, N. L; MORAES2, A; CARVALHO, P. C. F; MAGALHÃES, J. A. Acúmulo de forragem e morfogênese de Trachypogon plumosus sob níveis de fósforo. PUBVET, v.10, n.5, p.388-393, 2016.

DAVIES, A. Tissue turnover in the sward. In: DAVIES, A.; BAKER, R.D.; GRANT, S.A.; LAIDLAW, A.S. (Ed.). Sward measurement handbook, 2 eds., Reading: British Grassland Society, p.183- 216, 1993.

DIAS-FILHO, M. B. Degradação de pastagens: processos, causas e estratégias de recuperação. 4 eds. Belém, 2011. 215p.

DIAS， D.G.; PEGORARO， R.F.; ALVES, D.D.; PORTO, E.M.V.; SANTOS NETO, J.A.; ASPIAZÚ, I. Produção do capim Piatã submetido a diferentes fontes de fósforo. Revista Brasileira de Engenharia Agrícola e Ambiental, v.19, n.4, p.330-335, 2015.

DUARTE， C.F.D.; PAIVA， L.M.; FERNANDES, H.J.; CASSARO, L.H.; BREURE, M.F.; PROCHERA, D.L.; BISERRA, T.T. Capim-piatã adubado com diferentes fontes de fósforo. Revista Investigação, v.15, n.4, p. 5863, 2016.

DUARTE, C. F. D.; PAIVA, L. M.; FERNANDES, H. J.; BISERRA, T. T.; FLEITAS, A. C. Capim tropical manejado sob lotação intermitente, submetido a fontes de fósforo com diferentes solubilidades, associados ou não à adubação com nitrogênio. Ciência Animal Brasileira, v.20, n. 1,p1-15, e47692, 2019.

EMBRAPA, Empresa Brasileira de Pesquisa Agropecuária. Integração lavoura-pecuária-floresta: o produtor 
pergunta, a Embrapa responde. Brasilia, 2015, 393p.

EMBRAPA - Empresa Brasileira de pesquisa Agropecuária. Sistema Brasileiro de Classificação de Solos. $4^{\circ}$. ed. Brasília - DF: Embrapa Solos, 2014. 376p.

EMBRAPA, Empresa Brasileira de Pesquisa Agropecuária. Manual de Análise de Químicas de Solo, Plantas e Fertilizantes. Brasília $3^{\text {a }}$. ed. Revisada e ampliada. - Embrapa Informação Tecnológica, 2013. 627p.

INMET: Instituto Nacional de Meteorologia. Disponível em $<$ http://www.inmet.gov.br/portal/index. $\mathrm{php} ? \mathrm{r}=$ home/page \&page $=$ rede_estacoes auto_graf $>$ Acesso em: 02 de Mar. de 2019.

KÖPPEN, W. Climatologia: com um estúdio de losclimas de latierra. Climatology Laboratory of Climatology, New Gersey.p.104, 1948.

LANGER, R.H.M. How grasses grow. London. 1972. 60p.

LARA, M. A. S.; PEDREIRA, C. G. S. Respostas morfogênicas e estruturais de dosséis de espécies de braquiária à intensidade de desfolhação. Pesquisa Agropecuária Brasileira, v.46, n. 7, p. 760-767, 2011.

LEMAIRE, G.; OOSTEROM, E. van; JEUFFROY, M.-H.; GASTAL， F.; MASSIGNAM, A. Crop species present diferente qualitative types of response to $\mathrm{N}$ deficiency during their vegetative growth. Field Crops Research, v. 105, n. 0, p.253-265, 2008.
LUNA, A. A; DIFANTE, G S; ARAÚJO, I. M. M; LIMA, C. L. D; NETO, J. V. E; VASCONCELOS, R. I. G; OLIVEIRA, H. C. B.; DANTAS, s. L. s: Características Morfogênicas de Gramíneas Forrageiras no Nordeste do Brasil1. Revista

Científica de Produção Animal, v.14, n.2, p.138-141, 2012.

MARTUSCELLO, J.A.; FONSECA, D.F.; NASCIMENTO JÚNIOR, D.; SANTOS, P.M.; CUNHA, D.N.F.V. E MOREIRA, D.F. - Características morfogênicas e estruturais de capimmassai submetido à adubação nitrogenada e desfolhação. Revista Brasileira de Zootecnia, vol. 35, n. 3, p. 665-671, 2006.

OLIVEIRA, E. P.; SILVEIRA, L. P. O.; TEODORA, P. E.; ASCOLI, F. G.; TORRES, F. E. Efeito do sombreamento e do incrustamento de sementes sobre o desenvolvimento de cultivares de Panicum maximum Jacq. Biosciense Journal, v. 30, n. 6, p.1682- 1691, 2014.

PONTES, L. da S.; LOUAULT, F.; CARRÈRE, P.; MAIRE, V.; ANDEUZA, D.; SOUSSANA, J.F. The role of plant traits under their plasticity in the response of pasture grasses to nutrients and cutting frequency. Annals of Botany, v.105, n.6, p.957-965, 2010.

ROMA, C. F. C.; CECATO, U.; SOARES FILHO, C. V; SANTOS, G. T. dos; RIBEIRO, O. S.; IWAMOTO, B. S. Morphogenetic and tillering dynamics in Tanz ania grass fertilized and nonfertilized with nitrogen according to season. Revista Brasileira de Zootecnia, v. 41, n. 3, p. 565-573, 2012. 
SANTOS, M.E.R.; FONSECA, D.M.; GOMES, V.M.; GOMIDE, C.A.M.; NASCIMENTO JUNIOR, D.; QUEIROZ, D.S. Capim-braquiária sob lotação contínua e com altura única ou variável durante as estações do ano: morfogênese e dinâmica de tecidos. Revista Brasileira de Zootecnia, v.40, n.11, p.2323-2331, 2011.

SHAPIRO, S. S.; WILK, M. B. An Analysis of Variance Test for Normality, (Complete Samples). Biometrika, v. 52, n.3/4, p. 591-611, 1965.

SBRISSIA, A.F.; SILVA, S.C. Compensação tamanho/ densidade populacional de perfilhos em pastos de capim-marandu. Revista Brasileira de Zootecnia, v.37, p.35-47, 2008.

SILVA, A. C.; AROUCHA, E. M. M.; CHAVES, S. W. P.; MEDEIROS, J. F.; PAIVA, C. A.; ARAÚJO, N. O. Efeito de diferentes doses, formas de aplicações e fontes de $P$ na conservação de melancia sem sementes. Horticultura Brasileira, v. 34, n. 4, p. 529-536, 2016.

SILVEIRA JUNIOR, O.; SANTOS, A.C.; RODRIGUES, M.O.D.;
RODRIGUES, M.O.D.; ALENCAR, N.M. Productive efficiency of mombasa grass in silvopastoral system under pasture deferment and nitrogen fertilizer. Semina: Ciências Agrárias, v. 38, n. 5, p. 3307-3318, 2017.

TAIZ, L. E ZEIGER, E. (2009) - Fisiologia vegetal. Porto Alegre, Artmed. 819 p.

TORRES, F. E.; OLIVEIRA, E. P.; TEODORO, P. E.; RIBEIRO, L.P.; OLIVEIRA, E. P; OLIVEIRA, M. V. M; SILVA JUNIOR, C. A; CORREAA, C. C. G. Doses Of Phosphorus On Initial Development And Forage Production Of Cultivars Of Panicum Maximum, Bioscience Journal., v. 32, n. 6, p. 15371544, 2016.

ANDA- Associação Nacional Para Difusão De Adubos - Anuário do setor de fertilizantes 2017. São Paulo: ANDA, 176 p. 2017.

SANTOS, H.C.; OLIVEIRA, F.H.T.; SALCEDO, I.H.; SOUZA, A.P.; SILVA, V.D.M. kinetics of phosphorus sorption in soils in the state of Paraíba. Revista Brasileira de Ciência do Solo, v. 35, n. 4, p. 1301-1310, 2011. 